\title{
Hoofdstuk II
}

\section{Een nieuw begin onder Bataafse, Franse en Britse vlaggen (1800-1816)}

\section{Bestuur rond de eeuwwisseling}

De bekende patriot en criticus van het oude regime, Dirk van Hogendorp, had bij zijn terugkeer in patria na zijn opzienbarende vertrek uit Batavia de toestand van het genootschap aan het eind van de eeuw niet bondiger kunnen weergeven dan met de beginzin van de paragraaf over 'Konsten en Weetenschappen' in zijn bekende Berigt van den tegenwoordigen toestand der Bataafsche bezittingen in Oost-Indiën: 'Batavia heeft een Genootschap van Konsten en Weetenschappen gehad, en zulks bestaat in naam nog' (Van Hogendorp 1799:132). Hij zei zich te schamen er meer over te zeggen en noemde de aanstelling van de gouverneur-generaal en de raden van Indië tot opperdirecteuren bij de oprichting in 1778 een 'slaafsche stap', bedoeld om vervolging te voorkomen in 'het rijk van geweld en dwingelandij'. De drie voorzitters tot 1799 kregen er van langs: Radermacher was niet geleerd, maar had zich dan in ieder geval nog een voorstander van kunsten en wetenschappen getoond. De tweede voorzitter - Moens' naam werd niet genoemd - was alleen gekozen omdat 'hij ten minsten geen kwaad aan de zaak zoude doen' en onder Wiegerman, 'die naauwelijks zijn naam kan schrijven, en zelfs niet recht weet, of hij een Nederlander of een Duitscher is', was het genootschap 'zo goed als tot niet geraakt' (Van Hogendorp 1799:132-3). Van Hogendorp, die zelf in 1784 lid was geworden van het genootschap, kan door zijn vader Willem zijn ingelicht over de toestand in het genootschap in de beginjaren. Willem van Hogendorp behoorde immers tot de oprichters en tot de groep bestuursleden van het eerste uur.

Dirk zelf, als geducht patriot de geest van de nieuw tijd goed aanvoelend, brak zijn staf over de oude orde in Batavia. Onder de dwingelandij van de vijanden van de Verlichting kon geleerdheid niet bloeien. Het was nog opmerkelijk dat het genootschap 'merkwaardige en wel uitgewerkte stukken' had uitgegeven in een wereld zonder 'nieuwspapieren of couranten'. Hij verwees zoals elders in zijn geschrift naar de veel gunstiger situatie in de Engelse 
koloniën en voorzag een periode van bloei voor de kunsten en wetenschappen zodra er vrijheid zou heersen.

Indien wij het geluk mogen hebben, de vrijheid op Batavia en Java eens te zien invoeren, dan zal het genootschap van konsten en weetenschappen, bestuurd door mannen van verstand, kunde en geleerdheid, die tot hun voorzitter niet een Edelheer, maar den verstandigsten uit hun midden zullen verkiezen, weder herleeven, en door zijne werkzaamheden het licht der waarheid, zoo wel over Java als over onze andere bezittingen in Oost-Indië, alom verspreiden (Van Hogendorp 1799:133-4).

Dat de woorden van Van Hogendorp in de kring van het genootschap enige weerklank hebben gevonden, is aannemelijk. Andries Teisseire en Carel van Naerssen zaten al sinds 1789, respectievelijk sinds 1791 in het genootschapsbestuur. $\mathrm{Zij}$ hadden in december 1795 behoord tot de adressanten die het oude bewind onder gouverneur-generaal Alting en commissaris Nederburgh hadden opgeroepen om de nieuwe vrijheid, die met de inval van de Fransen op de Bataafse Republiek was neergedaald, ook in de kolonie te omhelzen. Zij behoorden tot de groep van vijf die het adres aan de commissarissengeneraal kwam overhandigen, waarmee ze wel geen revolutie, maar dan toch een bescheiden hervormingsbeweging initieerden (Schutte 1974:157). Een van de vraagpunten, het zoveel mogelijk afschaffen van 'de uiterlyke tekenen van distinctie' (Schutte 1974:158), komen we ook tegen in de eerste signalen van de ommekeer in het genootschap in 1800. Het Parijse gelijkheidsideaal van 1789 drong zo in december 1795 tot Batavia door en, voor zover wij dat kunnen reconstrueren, eerst in maart 1800 tot het genootschap.

De bijeenkomsten van het genootschapsbestuur van het jaar 1800 zijn daarom zo belangrijk, omdat na vijf jaar van nagenoeg gehele rust het oude regime in de vorm van de Bataviase regering als hoogste orgaan van het genootschap werd afgeschud. $\mathrm{Nu}$ had die regering in de onzekere jaren van isolement en oorlogsdreiging veel aan gewicht ingeboet en ook had zij geen hand uitgestoken om het verval in het genootschapsleven te stuiten. Nadat Wiegerman in 1799 was overleden, kwamen op 31 maart 1800 de zeven overgebleven bestuursleden voor het eerst sinds jaren weer bij elkaar. Wiegerman was de enige in het bestuur geweest die de oprichting nog had meegemaakt. Het bestond nu uit Frederik Schouwman (sinds 1784 bestuurslid), Andries Teisseire (1789), Jeremias Schill (1790), Johan Theodorus Ross (1790), Carel van Naerssen (1791), Albertus Henricus Wiese (1794) en Willem Michaël Döckers (1794). Deze mannen trokken zich de 'veragterde toestand van zaaken en belangen des genootschaps' aan. Zij zorgden voor een Bataafse revolutie in het klein. De 'uiterlijke tekenen van distinctie', die in het verleden de verhoudingen binnen het genootschap in belangrijke mate bepaalden, werden afgeschaft. Er werd gekozen voor - wat in maart 1800 nog heette - 
'eene meer eenvoudige inrigting, bij minder ostentatie, en bepaalder inzigten', maar wat twee maanden daarna niets minder bleek te zijn dan het aan de kant zetten van de Hoge Regering als opperdirecteuren van het genootschap: 'Het geheel bestier der zaaken [...] zal staan aan eene Vergadering van Dirigeerende Leden'. Dit nieuwe bestuur zou zichzelf aanvullen en het voorzitterschap zou onder de bestuursleden rouleren. ${ }^{1}$ De relatie met de regering zou beperkt blijven tot één bezoek per jaar, af te leggen door de voorzitter, een tweede bestuurslid en de secretaris, met als doel de bescherming van de regering te verzoeken. ${ }^{2}$ Daarmee was in de keurige woorden van het bestuursverslag de kleine revolte voltooid. Kunde en bekwaamheid waren criteria geworden voor het lidmaatschap, rang en stand waren in onbruik geraakt, aanzien werd als selectiecriterium afgeschaft. In augustus 1802 werd nadrukkelijk besloten de 'kwaliteiten' van de leden - functies en titels - niet meer in de ledenlijst op te nemen. ${ }^{3}$ Tenslotte werd het instituut van de algemene vergadering opgeheven en werd de hoogte van de contributie aan de welwillendheid en draagkracht van de leden overgelaten. Door de hoogte van de contributie vrij te laten, werd de poort opengezet naar een grotere groep belangstellenden. Tegelijk werd met het afschaffen van de algemene vergadering de stem van die nieuwe leden bij voorbaat gesmoord. De Raad van Indië stemde met de voorgestelde wijzigingen in, ook met het verlies van de eigen positie in het genootschap. ${ }^{4}$ Overigens zou later in het genootschap een tegenbeweging zichtbaar worden. In dat opzicht weerspiegelen zich in het genootschap de bewegingen en contra-bewegingen van de jaren 17951816 in moederland en kolonie.

Dat in de vijf jaar voorafgaande aan de democratische ommezwaai zo goed als niets was gebeurd, was treurig genoeg. Het is juist de stilstand in de genootschapsactiviteiten van die jaren, die Van Hogendorp zijn sarcastische woorden ingaf. De Bataviase bevolking en vooral de elite waaruit het genootschapsbestuur werd gerecruteerd, had wel iets anders aan het hoofd gehad dan het beheer van de boeken en de verzamelingen in Radermachers huis. Het uitgeven van Verhandelingen en het uitschrijven prijsvragen leken futiele bezigheden in vergelijking met wat er in Europa en op de wereldzeeën gebeurde. De zorgen om het genootschap vielen in het niet bij de ondergang van de VOC en de dreigende inval van de Fransen, die de koloniën zouden willen bezetten om te voorkomen dat ze in de handen van de Engelsen vielen. Alleen de brave genootschapssecretaris Ross had er in de jaren 1795-1799 voor gezorgd dat op de genootschapszaken was gelet. In Van Hogendorps Berigt

ANRI KBG Dir 0020, 334-339, vergaderingen 31-3-1800 en 2-5-1800.

ANRI KBG Dir 0020, 342.

ANRI KBG Dir 0020, 345, vergadering 2-8-1802.

ANRI KBG Dir 0020, 345. 
was Ross daarvoor met ere genoemd. ${ }^{5}$ We mogen aannemen dat hij naast het beheer van de financiën ook toezicht was blijven houden op het genootschapshuis. In 1802 nam hij die taak ook weer formeel op zich. Opnieuw was het een predikant, die belangrijk onderhoudswerk verzette.

Daarmee lijkt Johan Theodoor Ross (1755-1824), werkzaam bij de Nederduitse gemeente, degene geweest te zijn die het genootschap door zijn moeilijkste jaren heenhielp. Misschien verdient hij naast Raffles daarom de titel van redder van het genootschap. Hij werd daarvoor in de vergadering van 2 augustus 1802 door zijn medebestuursleden bedankt. ${ }^{6}$ Ross was in 1788 aangekomen en in 1790 tot het genootschap toegetreden. Hij zou in 1808 door Daendels tot professor-honorair in de theologie worden benoemd in een stad waar geen universiteit was. In deze hoedanigheid werd hij in 1812 door Raffles bevestigd. In 1816 werd hij korte tijd voorzitter van het genootschap, terwijl hij eerder onder Raffles als secretaris was blijven dienen. Hij droeg in 1816 het secretariaat over aan pastoor Ph. Wedding. ${ }^{7} \mathrm{Na} 26$ jaar in het bestuur, begonnen onder Adriaan Moens, zal hij zelfs daarna nog, tot zijn dood in 1824, als vraagbaak hebben gediend voor latere secretarissen.

In het bestuur was in de twee jaar sinds 1800 al weer heel wat veranderd. Tesseire was overleden, Wiese en Schouwman waren afgetreden, Van Naerssen was vertrokken. De nieuwe bestuursleden die op 2 augustus 1802 aantraden waren Jan Jacob Vogelaar, Christaan Arnold, Louis Zomerdijk, Josua Leistman en Jan Kloprogge. Er waren achttien nieuwe leden benoemd. ${ }^{8}$ Van de hoopvolle nieuwe impuls die het genootschap zich zelf had gegeven, inclusief een nieuw reglement, is verder weinig zichtbaar, althans weinig achterhaalbaar in de eerste jaren van de eeuw. In de laatste vergadering van 1802, op 7 december, kwam een pakket uit Haarlem binnen met een brief uit 1794 (na acht jaar onderweg te zijn geweest), schonk voorzitter Vogelaar zeven koperen platen met 'fraai gesneden Oostersch schrift' en werd het pas gedrukte reglement (de nieuwe inrichting) getoond. ${ }^{9}$ Van dat drukwerkje heb ik geen enkel exemplaar in handen kunnen krijgen. De inhoud zal zijn overeengekomen met wat de resolutiën van 1800 daarover al hadden gezegd.

5 Van Hogendorp 1799:132. Ross heeft ook de financiën van jaar tot jaar bijgehouden, zo blijkt uit het verslag van de vergadering van 31 maart 1800 . Het saldo bedroeg toen Rds 1117.361/2.,- (ANRI KBG Dir 0020, 334-337, vergadering 31-3-1800).

6 ANRI KBG Dir 0020, 343-349, vergadering 2-8-1802.

7 De Haan 1935b:633-4. ANRI KBG Dir 1505, nr [17], overdracht van het secretariaat van Ross aan Wedding.

8 ANRI KBG Dir 0020, 346, vergadering 2-8-1802.

9 ANRI KGB Dir 0020, 353, vergadering 7-12-1802. Van dat drukwerkje heb ik geen enkel exemplaar kunnen terugvinden. De uitgave wordt vermeld in het Voorberigt VBG 7 (1814):2. Vanwege de zeldzaamheid nam Der Kinderen 1878 de tekst uit de resolutien in het archief als bijlage op. 
Juist hier is het resolutieboek van 1783-1802 vol en moest de secretaris overgaan naar een nieuw deel, het vierde sinds de oprichting in 1778. Maar dit vierde deel ontbreekt in het genootschapsarchief, zodat we pas weer met het resolutieboek van 1821 geïnformeerd zijn over de bestuursvergaderingen. Tussen deze jaren (1802-1820) ligt de belangrijke, later steeds bezongen periode van Raffles' voorzitterschap. Het is niet aannemelijk dat Ross, steeds een stipt werkend secretaris, in deze jaren geen verslagen heeft gemaakt. Het is waarschijnlijker dat dit resolutieboek is weggeraakt. Bij de overdracht van het secretariaat in 1816 van Ross aan Wedding werd het aantal resolutieboeken dat de nieuwe secretaris in handen kreeg, geteld als vier. Daarvan zijn er slechts drie terug te vinden in het genootschapsarchief, en wel over de periode $1778-1802 .{ }^{10}$

Zo hebben we over de periode vanaf 1803 te maken met een groot gat en zijn we alleen ingelicht door bronnen buiten het genootschapsarchief en bronnen van later datum. Het doorgaans goed ingelichte bestuurslid dominee W.R. van Hoëvell deed in zijn geschiedkundig overzicht van kunsten en wetenschappen in de kolonie (1839) wel een boekje open, maar juist over de periode na de 'omwentelingen in Europa' (1795) is hij weinig precies.

Het werd zelfs noodzakelijk den kring der werkzaamheden aanmerkelijk te beperken, de algemene vergaderingen te staken, en de verzamelingen van het Genootschap onder de leden des bestuurs te verdeelen, opdat deze ze tot meer gunstige tijden als eigendom des Genootschaps mogten bewaren (Van Hoëvell 1839:53).

Van Hoëvell gaat in zijn relaas verder met de Vrede van Amiens (1802), zodat wij mogen aannemen dat genoemde mededeling betrekking heeft op de jaren 1795-1802. We moeten er echter van uitgaan dat Van Hoëvell ook toen (1839) niet kon beschikken over een uitgebreid genootschapsarchief voor de jaren 1802-1820. Hij moet de informatie over de opgedeelde verzamelingen uit mondelinge overlevering hebben gehad, maar als bewijs dat de verzamelingen inderdaad waren verdeeld, is het niet overtuigend.

We tasten echter niet helemaal in het duister over de activiteiten tot de komst van de Engelsen in 1811. In een bundel losse stukken over de periode 1817-1827 zit in het genootschapsarchief een tot 1815 bijgewerkte ledenlijst die als kopij heeft gediend voor deel 8 van de Verhandelingen (1816). De lijst is - evenals zijn gedrukte pendant - chronologisch ingericht naar het criterium:

10 ANRI KBG Dir 0001-0020 bestaat uit drie banden. De vierde bundel wordt genoemd in ANRI KBG 1505 (bundel losse stukken over de periode 1817-1827), nr [17], transport RossWedding. Ook Der Kinderen heeft het over een gat in het genootschapsarchief tussen 1802 en 1821. Hij heeft echter een ledenlijst van 1815 in de bundel ANRI KBG 1505 kennelijk niet in handen gehad. Daar vallen nog wat gegevens uit af te lezen. 
van het oudste lid tot het jongst aangekomen lid. Bovendien is bij de namen van alle in 1815 nog aanwezige leden de datum van de vergadering waarop zij tot het lidmaatschap werden uitverkoren, genoteerd. Zo zien we dat in 1815 nog slechts twee personen van het eerste uur (1778) aanwezig waren. Het ging om de oud-gouverneur-generaal J. Siberg (1801-1805) en W.V.H. van Riemsdijk, beiden afkomstig uit vooraanstaande Bataviase families en al zevenendertig jaar lid. In totaal waren nog maar zestien leden over van vóór 1795. Nog gelukkiger is dat de opsteller van de lijst ook voor de periode na 1802 heeft opgegeven wanneer de opgesomde nieuwe leden werden benoemd. Dat moet in bestuursvergaderingen zijn gebeurd. ${ }^{11} \mathrm{Zo}$ zien we dat er in 1803 minstens een keer is vergaderd, in 1806 twee keer, in 1807 en 1809 elk een keer. De opsteller van de lijst moet te rade zijn gegaan bij een resolutieboek, anders had hij niet zo precies kunnen weten wanneer ieder tot het lidmaatschap was verkozen. Zo kunnen wij zien dat er tegenover zestien leden die het oude regime nog hadden meegemaakt, nog eens zestien leden stonden die tussen 1802 en 1811 waren aangetreden en opnieuw vijfenveertig nieuwkomers tussen 1812 en 1815. Van hen hadden acht Franse namen en drieëntwintig Engelse, zodat het genootschap een echte internationale organisatie was geworden. ${ }^{12}$ Het betekent dat het genootschap rond 1810 ongeveer dertig Bataviase leden geteld zal hebben. Van leden op buitenkantoren was al lang niets vernomen. Een enkele brief van Christiaan Hoffmann uit Ambon (1802) in het genootschapsarchief over zijn inentingsactiviteiten tegen de pokken, 'deeze eerste kunst bewerking en derzelve heilzame uitwerking' bewijst dat de contacten minimaal waren. Hoffmann wist niet van Wiegermans dood, evenmin kennelijk van Van Hogendorps en Van der Steeges uitgebreide rapporten over de pokkeninenting, maar wist wel dat hij bij het genootschap moest zijn voor zijn rapportage. Zijn verslag gaat terug naar zijn eerste pogingen in 1787 om de inenting bij de ongelovige gelovigen aanvaard te krijgen. Net als Horsfield in dezelfde tijd, had Hoffmann een steuntje in de rug nodig. ${ }^{13}$

C.G.C. Reinwardt, die in 1816 met de Commissie-Generaal op Java aankwam en in wiens portefeuille na het herstel van het Nederlandse gezag op Java de zorg voor kunsten en wetenschappen was ondergebracht, deed het in 1821 in een toespraak tot de algemene vergadering van het genootschap voorkomen alsof in de jaren 1792-1806 voortdurend was vergaderd. Sprekend over die periode zei hij - de notulant is pastoor Wedding:

\footnotetext{
11 ANRI KBG Dir 1505, nr [15-16]. Twee exemplaren van de bedoelde lijst.

12 Op de lijst zijn de namen van de inmiddels overleden leden doorgestreept. De manuscriptversie in het archief wijkt in geringe mate af van de gedrukte versie in VBG 8 (1816).

13 ANRI KBG Dir 1507, brief van Christiaan Hoffman aan president en leden van het Bataviaasch Genootschap, Amboina 14-6-1802.
} 
De Omstandigheden in Europa werden meer en meer bedenkelijk en het 6e deel der Verhandelingen [1792, HG] toont ons reeds, dat het Genootschap niet meer konde voortgaan om de vruchten van haren arbeid door den druk publiek te maken.-Niet tegenstaande de daarop volgende bijna gehele Afscheiding van deeze Colonie van het Moederland, zogten altoos de ijverige bestierers van dien Tijd, het Genootschap, hoe wel kwijnend, in het Leven te houden. De maandelijksche vergaderingen der dirigerende Leden van het zelve, werden altoos volgehouden en uit de spaarzaam uitkomende Vaderlanders, werden altoos ijverig nieuwe Leden in plaats der overledenen gesteld. ${ }^{14}$

Hoe juist Reinwardt was geïnformeerd, is nog de vraag. Was hem misschien het verleden door Ross wat te rooskleurig voorgesteld? In ieder geval bevestigen zijn woorden wat ook de eerder genoemde ledenlijst ons zegt: er werd vergaderd, er werden nieuwe leden gekozen, ook vóór 1811. Reinwardt en Van Hoëvell spreken elkaar volledig tegen. De een houdt het op maandelijks vergaderen, de ander op helemaal niet vergaderen.

\section{Persoonlijkheden: Thomas Horsfield, Amerikaans natuurkundige}

Het is frustrerend dat we over de activiteiten tot de komst van de Britten niet meer weten dan enkele namen van leden gekoppeld aan de datum van bestuursvergaderingen. Van Hoëvell meldt dat Ross in die jaren aan het hoofd van het genootschap stond, maar hij meldt niets concreters over het genootschap dan dat het betrokken was bij de activiteiten van de Amerikaanse plantenkundige Thomas Horsfield, die in 1802 tot lid was benoemd en zeventien jaar in de archipel zou blijven, voornamelijk op Java. ${ }^{15}$ De Britse historicus John Bastin heeft uit diverse bronnen een uitvoerig biografisch Memoir over Horsfield samengesteld, dat als inleiding diende tot de heruitgave van diens Zoological researches in Java, and the neighbouring islands. ${ }^{16}$

Horsfield (1773-1859) was in 1798 in de medicijnen gepromoveerd aan de universiteit van Philadelphia, had in 1800 als scheepsarts Batavia aangedaan en was er in 1801 teruggekeerd met de bedoeling langer te blijven. Hij werd in 1802 tot opperchirurgijn benoemd in gouvernementsdienst met als opdracht onderzoek te doen naar inheemse kruiden en planten (Horsfield 1990:7-8, Memoir). Zelf zegt hij van een eerste verslag over geneeskrachtige planten

\footnotetext{
14 Verslag van de algemene vergadering van 21-2-1821 in de hand van Wedding in ANRI KBG Dir 0022.

15 Van Hoëvell 1839:54-6. Horsfield was een van de leden die op 2-8-1802 werden benoemd. ANRI KBG Dir 0020, 345.

16 Horsfield 1990, oorspronkelijk verschenen in Londen 1821-1824. Bastin noemt Horsfield in de titel van zijn Memoir 'First American naturalist of Indonesia' (Bastin 1990).
} 
dat voor advies naar het Bataviaasch Genootschap ging:

This report was submitted to the Council of the Batavian Society of Arts and Sciences, and through the recommendation of that body I received a more extensive appointment which offered me an opportunity to extend my researches not only to the Vegetable Kingdom, but also to Zoology and Geology, although the Materia Medica of Java was at this time still the chief object of my attention (Horsfield 1838-52:1, postscript; Bastin en Moore 1982).

In de samenvatting uit 1852 geeft Horsfield een ontwikkeling weer die over de jaren plaatshad. In het gouvernementsbesluit van 3 maart 1803 ging het de regering eerst en vooral om geneeskrachtige planten (Horsfield 1990:11, Memoir). Het genootschap gaf begin 1804 opnieuw een gunstig advies op Horsfields verzoek om na korte trips uit 1802 in de omgeving van Batavia nu een langere reis te mogen ondernemen. De toestemming van het gouvernement werd na het ontvangen van dit advies verkregen en in mei 1804 vertrok hij voor een reis over Java die hem pas weer in september 1812 naar Batavia zou terugvoeren. Tijdens deze jaren ontwikkelde Horsfield zich verder van medicus tot plantenkundige, dierkundige en geoloog.

Tijdens die acht jaren rapporteerde hij regelmatig aan het Bataviaasch Genootschap en het gouvernement, zo blijkt uit het relaas uit 1812, dat hij voor Raffles samenstelde over zijn activiteiten in de eerste jaren op Java. Zeven van zijn opstellen uit de jaren 1803-1806 werden pas in 1814 door het genootschap gedrukt, maar dat uitstel had te maken met gebrek aan drukletter en andere drukkersbenodigdheden in het door oorlogsomstandigheden geïsoleerde Batavia. Er kwam tot 1814 niets van de drukpers in de serie Verhandelingen. Het zevende deel was twintig jaar eerder in de druk blijven steken. ${ }^{17}$ De opstellen van Horsfield, gevoegd bij oude artikelen van twintig jaar eerder, completeerden het nieuwe deel 7. Zijn vele bijdragen in de Verhandelingen (1814-1816), merendeels teruggaand op observaties van zijn reizen in de jaren 1803-1812, wijzen erop dat de vertraging van de druk niet aan hem lag. Met Raffles als voorzitter werd de uitgave hervat met een dubbele, Nederlands-Engelse titel, Transactions / Verhandelingen.

Rond de jaarwisseling van 1805-1806 stuurde Horsfield dubbele exemplaren van geneeskrachtige kruiden naar het genootschap en hij rapporteerde in maart 1806 over zijn vorderingen vanuit Oost-Java. Het Bataviaasch Genootschap was dus voor hem de organisatie waarop hij steunde. Hij wist dat bij toekomstige verzoeken het gouvernement weer advies zou kunnen vragen aan het genootschap (Horsfield 1990:19-21, Memoir). Op een van zijn

17 Een zeldzaam exemplaar van dl 7 van de VBG (1794) heeft de UB Leiden G 150 7. Blijkens correspondentie in het familie-archief Beth (ANRI T 93 B 713/8) zijn er exemplaren hiervan rondgestuurd. 
reizen (1806) ontmoette hij de Franse natuurkundige J.B.L.C.Th. Leschenault de la Tour, een collega, die net als Horsfield eerst in Batavia lid was geworden van het genootschap, alvorens zijn onderzoekingen op Java te beginnen. ${ }^{18}$ De aanwezigheid van deze beide natuurkundigen laat zien dat het gouvernement geen moeilijkheden in de weg legde aan wetenschappelijk onderzoek of wetenschappelijke reizigers. In het geval van Horsfield stimuleerde de overheid het onderzoek in samenspraak met het genootschap. Leschenault de la Tour bracht bezoeken aan het Tengger-gebergte en het Ijen-plateau, waarvan hij verslag deed ${ }^{19}$ en hij werd in Oost-Java ingeschakeld door de gouverneur van Java's Noord-Oost-kust, N. Engelhard, bij het aanleggen van een particuliere, botanische verzameling (De Haan 1912-14, I:85). In het bestuur was zelfs iemand als Ross, die in andere tijden nog had meegemaakt dat het genootschap meer profiteerde van de overheid, niet in staat om van het in Indië aanwezige potentieel beter gebruik te maken. Horsfields langdurige afwezigheid uit Batavia en de gebrekkige communicatie met wetenschappers in Europa leidden ertoe dat zijn publicatie over experimenten met het gif van de Oepasboom te laat kwam. De experimenten waren in 1806 gedaan, het verslag pas in 1814 gepubliceerd. Leschenault de la Tour had er in 1809 in Parijs al over gepubliceerd. Het is een voorbeeld van het grote nadeel van de afstand Europa-Azië bij het verbreiden van wetenschappelijke ontdekkingen. In 1814 zou Marsden Raffles op de publicaties wijzen, die sinds 1809 over dit onderwerp waren verschenen (Horsfield 1990:38, Memoir). Horsfields opstel over dit onderwerp was toen net gedrukt $(V B G 7,1814)$.

Raffles zou direct op zijn eerste reis over Java, enkele maanden na zijn aankomst in 1811, een uitgebreid onderhoud met Horsfield hebben in Soerakarta en goed gebruik maken van diens kwaliteiten. ${ }^{20}$ Het kan niet anders of we moeten - zelfs bij de onzekerheid door het ontbreken van een deel van het genootschapsarchief - besluiten dat het genootschap in de periode tot 1811 zwak bemand was en weinig middelen bezat. Geld (bij Engelhard) en macht (bij Raffles) bewerkten wat het machteloze en arme genootschap niet wist te bereiken. Horsfield werd door de opeenvolgende landvoogden, DaendelsJanssens-Raffles-Fendall, steeds weer in zijn functie aangehouden, teken dat

18 Horsfield in zijn 'Memorandum' (1829) over zijn verhouding tot Raffles, geschreven op verzoek van Lady Sophia Raffles (S. Raffles 1991:630). Leschenault de La Tour werd op 16-11-1806 lid van het genootschap (ANRI KBG Dir 1505, nr [15-16]) en zou nog datzelfde jaar op reis zijn gegaan op Java, aldus Horsfield.

19 Afschrift van verslagen in de Mackenzie-collectie in Oriental and India Office Collection (OIOC London), Eur. Mss minor coll. 288-4 en 288-5 Mack.Pr.7. Ook 288-13 en 288-14. De beschrijving van Tengger is van 15-2-1806. Raffles zou deze verslagen van Engelhard gekregen kunnen hebben.

20 Hierover Horsfield in S. Raffles 1991:603. Zie ook Wurtzburg 1984:196 en De Haan 1912-4, $\mathrm{IV}: 2262$. 
het gouvernement zich bewust was van het belang van dit soort onderzoek. Daendels gaf Horsfield opdracht om afschriften te maken voor het gouvernement van alle stukken die hij tot 1808 bij het Bataviaasch Genootschap had ingediend en Janssens vroeg nog in 1811 aan het genootschapsbestuur hoe het gouvernement het beste gebruik kon maken van diens talenten (Horsfield 1990:29, 32, Memoir). Zo bleef de Amerikaan van 1802 tot 1811 steeds in contact met het genootschap. Overigens was Horsfield het genootschap jaren later nog dankbaar voor de aanbeveling bij het gouvernement toen hij nog opperchirurgijn was, aanbeveling waaraan hij mede zijn grote bewegingsvrijheid en bijbehorende bezoldiging te danken had (Horsfield 1838-52:1, Postscript).

Het genootschap zelf kon zich in 1814, terugblikkend op de jaren 18021811 in het 'Voorberigt' tot het eindelijk verschenen zevende deel van de Verhandelingen, geen andere wapenfeiten herinneren dan de komst van Thomas Horsfield en zijn indiensttreding bij het gouvernement na het gunstige advies. Nogal moedeloos rechtvaardigt de opsteller van het voorbericht, J.I. van Sevenhoven, de stilstand van die jaren.

Geen wonder dat in zulke duisterheid der tijden, in zoo benarden en afgesneden toestand, waarin deze kolonie zich bevond, en onder het weg sterven van vele nutte Leden, die niet te herplaatsen waren, de lust der overblijvende kwijnde of vergong, en de Letter-oefeningen meestal stilstonden (VBG 7, 1814:6).

En Raffles zelf rechtvaardigde in een toespraak tot de algemene vergadering op 24 april 1813 onder verwijzing naar dezelfde omstandigheden de geringe activiteit met de woorden: 'Cut off from all communication with the Mothercountry, and distracted by internal jealousies and disputes, Science drooped, and this Society, which at one time maintained so distinguished a character, almost ceased to be known' (VBG 7, 1814:3).

Bronnen van vóór 1811 zijn schaars: de Bataviasche Koloniale Courant, opgericht door Daendels, nam in de periode 1810-1811 niets op wat op activiteiten van het genootschap wijst, terwijl de Java Government Gazette na september 1812 wel met regelmaat vergaderingen van het genootschap meldde en versloeg. Na de vergadering van juni 1809, waarvan we alleen weten dat er twee leden werden benoemd, zijn we tot januari 1811 niet geïnformeerd. Bij cartografische actviteiten, zoals die onder Daendels werden ondernomen voor de aanleg van de Postweg, was het Bataviaasch Genootschap niet betrokken. We vragen ons af of de bibliotheek en de verzamelingen in het genootschapshuis aan de Grote Rivier een desolate indruk maakten rond 1811. Kwamen er nog wel eens mensen? Was zo te zien tussen 1795 en 1800 nog voorzien in klein onderhoud door een aantal uitgaven, zoals voor de bibliothecaris, de schrijver, de jongen en de meid (slaven), over de toestand in het huis na 1802 weten we niets. 


\section{Bestuur onder Raffles}

Hoeveel te meer is er bekend over de periode van Thomas Stamford Raffles (1781-1826). Een snelle blik op het materiaal laat al zien dat hij zijn eigen publiciteit verzorgde. Na jaren kwamen er weer Verhandelingen uit, waarin zijn toespraken stonden, die in feite het genootschapsprogramma verwoordden. Hij was daarmee de strateeg van het genootschap. Raffles bleef Horsfield steunen en zorgde ervoor dat diens werk gepubliceerd werd: de helft van deel 7 en meer dan de helft van deel 8 van de Verhandelingen is van Horsfields hand. Andere Raffles' getrouwen: Colin Mackenzie, John Leyden en John Crawfurd zorgden voor de rest. Bijdragen van Nederlandse leden waren minimaal. Ook via de Gazette zorgde Raffles voor berichtgeving. Bovendien hielp hij het genootschap aan een nieuwe behuizing, aan de zijkant van de Harmonie, het nieuwe sociëteitsgebouw. Zijn uitgebreide verzamelingen en de boekstaving van zijn en andermans werk in zijn History of Java (1817) deden de rest. Daardoor kon Raffles de geschiedenis ingaan als de persoon die het Bataviaasch Genootschap nieuw leven inblies en werd hij na Radermacher de tweede belangrijke figuur in de genootschapskroniek. De periode 1811-1816 verdient daarom nadere belichting. Echter geldt ook voor deze periode dat het archief weinig of niets bevat. Een deel van het materiaal blijkt met Raffles naar Londen te zijn gegaan.

De toestroom van Europeanen naar Batavia, die op de overname van Java door de Britten in september 1811 volgde, betekende een impuls voor het gezelschaps- en genootschapsleven. Waren de Britten tijdens de blokkades in de Frans-Engelse oorlogen eerder verantwoordelijk geweest voor het isolement van Java, waardoor de aanvoer van Europeanen stokte, nu zorgden ze voor ontsluiting. Raffles was geboren in de Caraïbische Zee aan boord van het schip waarop zijn vader kapitein was. Zijn moeder was Nederlandse. Als jongeman in dienst van de East India Company gekomen, werkte hij tot 1805 op het hoofdkantoor in Londen. Daarna werd hij naar Penang uitgezonden. Door governor-general Lord Minto werd hij in 1809 uitgekozen als diens agent voor de Maleise staten met als standplaats Malakka. Toen de invasieplannen voor Java in augustus 1811 werden uitgevoerd koos Minto Raffles tot zijn secretaris. De overmeestering door de Britten van het slecht verdedigde Java onder Janssens was in een maand gebeurd.

Raffles was zich direct bewust van het bestaan van het genootschap en van de noodzaak om aandacht te besteden aan de wetenschap. In een brief aan William Marsden, de auteur van History of Sumatra, van 5 oktober 1811, schrijft hij: 'Lord Minto is now here and we have in contemplation to bring forward the Batavian Asiatic Society as soon as circumstances permit' (Wurtzburg 1984:181). De passage is niet helemaal duidelijk: overwogen Minto en zijn luitenant-gouverneur Raffles een Bataviase afdeling van de Asiatic Society 
van Calcutta op te richten of verwees de brief naar de noodzakelijkheid om het Bataviaasch Genootschap vooruit te helpen? Ik houd het op het laatste. Wel geeft het aan dat Minto en Raffles nog geen maand na de val van Meester Cornelis al nadachten over wetenschappelijke activiteiten.Het zou overigens nog een jaar duren voordat het Engelse bestuur zodanig op orde was, dat de aandacht voor het Bataviaasch Genootschap tot iets leidde (Schrieke 1930).

Het eerste nieuwe lid van het genootschap in deze periode was overigens niet Raffles zelf maar de Schotse genie-officier, luitenant-kolonel Colin Mackenzie (1754-1821). ${ }^{21}$ Hij was in India werkzaam geweest als landmeter en cartograaf en had daar een historisch-archeologische verzameling aangelegd. Op de expeditie naar Java leek hij een geschikte persoon juist vanwege zijn cartografische vakkennis (Blake 1991). Hij kreeg direct na de overname een opdracht tot het inventariseren van kaarten en archieven in Batavia, maar ook op de Noord-kust, in de periode waarin de nieuwe overheid gegevens over de kolonie verzamelde. Hij legde en passant ook een eigen verzameling aan die nu als de Mackenzie Collection in de Oriental and India Office Collections van de British Library wordt bewaard, waar zich tevens een deel van Raffles' papieren bevindt. ${ }^{22}$

Het ligt voor de hand dat we Mackenzies uitverkiezing tot het lidmaatschap tijdens een bestuursvergadering op 28 september 1812 in verband brengen met zijn ambtelijke taak: gegevens uit de archieven bijeenzoeken, en met zijn hobby: verzamelen. Hij had de bibliotheek en de verzamelingen van het Genootschap of wat daarvan nog over was, misschien al bekeken vóór hij in november 1811 op een reis van negen maanden over Java vertrok. ${ }^{23}$ Zo niet, dan zal hij na terugkeer in Batavia zijn vondsten hebben willen afzetten tegen de collectie van het genootschap. Bij zijn terugkomst in augustus 1812 was hij als onderzoeker en verzamelaar bekend. Hij was in september, net als Horsfield, in Batavia en daarvan profiteerde het genootschap door beide mannen aan zich te binden. De Java Government Gazette vond de uitverkiezing tot lid van de militair een uitgebreid bericht waard, hetzelfde bericht waarin de hernomen activiteiten van het genootschap werden gemeld. Er werd gewag gemaakt van de grote verzamelingen die Mackenzie op zijn reis had vergaard. Dat de manuscripten enkele maanden eerder uit de kratonbibliotheek

21 Volgens de ledenlijst uit 1815 in ANRI KBG Dir 1505, nr [15-16] zou Mackenzie al op 3-21812 tot lid benoemd zijn. Dit wordt tegengesproken door een krantenbericht van 3-10-1812, Java Government Gazette, 4. Op 28 september zou volgens dezelfde ledenlijst Captain W. Robison zijn benoemd.

22 Over het gebruik dat Raffles maakte van het door Mackenzie verzamelde materiaal: Weatherbee 1978.

23 In de Mackenzie collection zitten verschillende stukken, meest vertalingen in het Engels, die in verband staan met het Bataviaasch Genootschap, maar ook bijvoorbeeld een vertaling van Van Hogendorps Berigt van den tegenwoordigen toestand in manuscriptvorm. 
in Djokjakarta waren meegenomen na de plundering van het paleis werd niet vermeld: 'he has obtained a variety of valuable and curious information and made large collections of antiquities, manuscripts and inscriptions' (Java Government Gazette 3-10-1812:4).

Mackenzie zou op basis van de verzamelde gegevens zijn hoogste chef, Lord Minto in Calcutta, rapporteren. Het uitgebreide dagboek van zijn verblijf op Java gevoegd bij zijn ambtelijke verslag en de verzamelingen laten zien dat hij systematisch en veel verzamelde. Zijn taak in de commissie voor het ontwerpen van een nieuw grondbelastingstelsel, waarvoor het opmeten van het hele landbouwareaal nodig was, vroeg ook wel om een systematische aanpak. ${ }^{24}$ Mackenzie was bij het genootschap als het ware een voorloper van Raffles. Deze zou een maand later, 23 oktober 1812, contact leggen: hij nodigde alle in Batavia overgebleven leden, dertig in getal, uit voor een diner bij welke gelegenheid Van Sevenhoven op verzoek van het bestuur een exposé gaf van de geschiedenis en de doelstellingen van het genootschap. ${ }^{25}$ Thomas Horsfield had de week daarvoor, op 14 oktober 1812, een paar interessante natuur-historische uiteenzettingen gegeven in een ledenvergadering. ${ }^{26}$ Zijn verzameling natuur-historische specimina zou naar het museum van de East India Company in Londen verscheept worden (Java Government Gazette 31-10-1812:2).

In september 1812 was zo het genootschap weer in het nieuws. De krant vermeldde voorzichtig dat de enkele jaren geleden gestaakte activiteiten van het genootschap waarschijnlijk zouden worden hervat. De luitenantgouverneur had zich tijdens het diner, in antwoord op Van Sevenhovens schets van de geschiedenis van het genootschap, opgeworpen als behartiger van zijn belangen

by removing any obstacles which a jealous policy might formerly have thrown in the way of liberal inquiry, by providing a more commodious place for their meetings, and facilitating the publications of their transactions by the Governement Press (Java Government Gazette 31-10-1812:2).

Een statutenwijziging werd voorgesteld, waartoe een commissie aan het werk toog.

Een nieuwe vergaderruimte en toegang tot de overheidsdrukkerij waren

\footnotetext{
24 Mackenzie 1952:100-70; De Haan 1935b:599-604; Weatherbee 1978:63-93.

25 Java Government Gazette, 31-10-1812, p. 2. De tekst van de toespraak van Van Sevenhoven ook in de OIOC, Mackenzie collection Mack Pr. 1 (minor collection 287). De vertaler was M.L. Mesman.

26 OIOC, Mackenzie collection Mack.Pr. 1 bevat een minuut van een nota door Van Sevenhoven over deze Horsfield-stukken, waaruit op te maken valt dat Van Sevenhoven het bestuur adviseerde over de publicatie.
} 
voor het genootschap belangrijke punten. Daendels had een begin gemaakt met het verplaatsen van het regeringscentrum naar Weltevreden en zo was het oude genootschapshuis van Radermacher aan de Grote Rivier een excentrische plek geworden. Daendels had de ongezonde kuststrook verlaten voor het gezonder geachte Zuiden. De gevolgen van het wonen en werken in de oude stad had het genootschap jarenlang aan den lijve ondervonden. Waardevolle bestuursleden stierven aan de lopende band, het ledenbestand moest steeds worden aangevuld. De toezegging van Raffles was daarom in meer dan een opzicht belangrijk: betere en nieuwe ruimte niet alleen, ook opnieuw centraal gelegen in een gezondere omgeving. Dacht niemand in die maanden aan de mogelijkheid om Horsfields verzameling in Batavia onder te brengen en aan het museum van het genootschap uitbreiding te geven? Mackenzie werkte in opdracht van Lord Minto, dus hij verzamelde voor het Britse gouvernement . Zijn 'eigen' (particuliere) verzameling nam hij als vanzelfsprekend mee. Horsfield was zijn werkzaamheden echter begonnen in dienst van de Bataafse regering, aangesteld als hij was in 1802. Kennelijk was het voor Raffles een uitgemaakte zaak dat deze verzamelingen Brits zouden worden. ${ }^{27}$ Overigens is het in zowel krantenverslagen als in Raffles' eigen programmatische toespraken veelbetekend stil op het punt van verzamelen van de kant van het genootschap. Kon dat maar beter aan de Britten worden overgelaten?

De krant vermeldt evenmin welke formele rol Raffles in oktober 1812 op zich had genomen. Hij wierp zich zeker op als beschermheer, maar vreemd genoeg komt het formele beschermheerschap in de krant niet ter sprake. Pas in februari 1813 werd Raffles voorzitter (president), terwijl toen op zijn voorstel besloten werd om Lord Minto het beschermheerschap aan te bieden. In de Verhandelingen $(7,1814)$ heet het dat Raffles eerst de open plaats van beschermheer op zich nam - dat moet dan in oktober 1812 zijn geweest waarna het genootschap daarna deze plaats aan Lord Minto aanbood. Na het gemankeerde beschermheerschap van Prins Willem V was zo voor het eerst die plaats bezet, overigens helemaal in tegenstelling tot de geest van 1800. In het nieuw ingerichte genootschap van toen was voor een beschermheer geen plaats geweest.

Vanaf september 1812 werd met regelmaat vergaderd. Verslagen werden gepubliceerd in de Java Government Gazette. Raffles' lidmaatschap komt echter niet in de krant voor. In de ledenlijst in het archief staat zijn naam bovenaan bij de vergadering van 15 februari 1813, de dag waarop nog zeventien

27 De Raffles collection in de OIOC London bevat correspondentie tussen Horsfield en gouvernementssecretaris Assey uit 1816 over de overdracht van de collectie aan het museum van de EIC, overdracht die dan ter kennis gebracht zal worden van de al aanwezige commissarissengeneraal (OIOC, Eur Mss 237, Mss Eur F 31, pp. 322-4). 
anderen lid werden. Er zouden later dat jaar nog zestien anderen volgen. Vierendertig nieuwe leden in één jaar tijd. Raffles zelf werd toen voorzitter, terwijl het genootschapsbestuur in de jaren ervoor geen vaste voorzitter had gekend, volgens de democratische 'inrichting' van 1800. In 1812 nog rouleerde het onder B.F.W. baron von Lutzow, de oud-legeraanvoerder, J. Paschen, Van Sevenhoven, oud-secretaris van de regering en H.W. Muntinghe, bij de Britse verovering president van de Raad van Justitie en raad extra-ordinair. Muntinghe was de enige van het bestuur die hoge functies in de regering bleef bezetten en die naast Ross in het kernbestuur van het genootschap onder Raffles overeind bleef. Vanaf 1813 was de Britse signatuur van het ledenbestand veel sterker. $H$. Muntinghe werd vice-voorzitter, terwijl Ross en Daniel Ainslie de secretarissen werden. De aankondigingen over het genootschap in de Java Government Gazette verschenen telkens in twee talen: de Nederlandse mededelingen ondertekend door Ross, de Engelse door Ainslie. In de redactiecommissie voor de Verhandelingen nam Mackenzie plaats en in de museumcommissie gouvernementssecretaris Ch. Assey. Raffles vervreemdde het oude bestuur niet helemaal van zich. Von Lutzow en Van Sevenhoven kregen een plaats in de redactie, het zogenaamde committee over de papieren. ${ }^{28}$ Jeremias Schill en Ross waren de enigen in het nieuwe bestuur van 1813 die nog de veranderingen van 1800 hadden meegemaakt.

\section{De relatie met de overheid}

Met Muntinghe naast Raffles aan het hoofd van het genootschap was de door de generatie van 1800 zo gewenste 'eenvoudige' inrichting niet in ere gehouden. Immers met de landvoogd en het tweede lid van de Council aan het roer was het genootschap meteen weer afhankelijk geworden van de overheid. Die overheid deed er vervolgens alles aan om die afhankelijkheid te bevestigen. Het gebruik van de gouvernementele drukpers en het vooruitzicht van een nieuw genootschapshuis deden het genootschap voelen dat het niet zelfstandig kon opereren. De Engelse vertegenwoordiging in de beide comités, voor de publicaties en het museum, betekende dat de Britten het genootschap goed controleerden.

In november 1812 was voor het eerst weer een algemene vergadering gehouden zonder ceremonieel, in het huis van Muntinghe. Op de verjaardag van het genootschap op 24 april 1813 werd een algemene vergadering gehouden met ceremonieel: in Government House en onder voorzitterschap

28 Java Government Gazette, 20-2-1813:2 noemt deze samenstelling. In 1814 bleek die alweer sterk gewijzigd. Zie het Voorberigt van VBG 7 (1814). 
van de luitenant-gouverneur van Java. ${ }^{29}$ De programmatische veranderingen van 1800, een eenvoudige inrichting, weinig ostentatie, geen algemene vergaderingen, waren teruggedraaid. Bij die veranderingen moeten we even stilstaan.

Was bij de democratische, nieuwe opzet van 1800 in het eerste artikel vooropgezet dat het genootschap zou bestaan uit 'de kundigste en geschiktste Lieden dezer Hoofdplaats, zonder eenige aanmerking van staat of rang', in 1813 was dit Franse gelijkheidsbeginsel geschrapt en stond voorop dat het genootschap 'onder de bijzondere bescherming van het Britsche Gouvernement [zou] blijven voortduren'. Die 'bescherming' was in 1800 niet afwezig geweest, maar stond toen duidelijk op het tweede plan. Zozeer waren de verlichte geesten van 1800 gespitst geweest op een breuk met het verleden dat zij de doelstellingen van het genootschap verschoven naar artikel 8, waar zij eerst wilden vastleggen dat het bestuur alle macht in handen had, een bestuur dat zich zelf door coöptatie zou aanvullen. Door de contributie vrij te laten hoopten de hervormers van 1800 het genootschap open te stellen voor al diegenen die in het verleden buitengesloten waren geweest door de hoogte van het bedrag, elf rijksdaalders per jaar. Dit alles werd onder toezicht van Raffles veranderd: in de nieuwe inrichting van 1813 waren zelfs vijf artikelen aan de leden gewijd. In 1813 stond 'eene zucht tot uitbreiding der Wetenschappen' aan de basis van een gewenst lidmaatschap, maar daaraan vooraf ging nog de eis van 'bekende braafheid', waardoor een ballotage-element werd ingevoerd dat nieuw was of liever gezegd: dat leek op het verafschuwde rang en stand van vóór $1795 .{ }^{30}$ De contributie en het entreegeld werden vastgesteld op tien Spaanse matten elk.

De opvallendste verschillen zijn derhalve duidelijk: in 1800 wilde het genootschap zich zelfstandig opstellen, in 1813 stelde het zich juist onder de bescherming van het Britse gouvernement. In 1800 zag het genootschap het bestuur als de kern van de organisatie en had het voor de leden weinig ontzag, schafte het zelfs de algemene ledenvergaderingen af. Daarmee gooide het met het badwater ook het kind weg, want wat was een genootschap zonder 'genoten'? En wat was de rol van de leden als die zich niet minstens een keer per jaar konden doen horen? De mannen van 1813 herstelden de leden in hun eer, daarmee ook de algemene ledenvergadering, terwijl de bestuursstructuur heel precies aan bepalingen werd gebonden. Toch was de herziening van 1813 een restauratie: gouverneur-generaal Minto als beschermheer en luitenant-gouverneur Raffles als voorzitter zorgden voor toezicht van

\footnotetext{
29 De Java Government Gazette gaf er pas op 4-12-1813 een verslag van omdat het de briefwisseling tussen Minto en het genootschap wilde afdrukken.

30 'Het conceptplan van Inrigting' is geciteerd naar bijlage E uit Der Kinderen 1878:xix-xxi. De 'Nieuwe Inrigtingen' van 1813 naar VBG 7, 1814:viii-xii.
} 
boven; het genootschap was zijn zelfstandigheid kwijt. Overigens was het genootschap, of in ieder geval Raffles, zich bewust van de 'terugkeer' tot de opzet van 1778. In zijn toespraak van 1813 althans maakte hij melding van de mooie vooruitzichten die zich openden nu het genootschap zich toelegde op zijn oorspronkelijke bedoelingen (VBG 7, 1814:2).

Wat de herzieners van 1813 onveranderd lieten, waren de grote lijnen van de doelstellingen, zoals die in een apart artikel waren opgenomen: zij streefden, naar de formulering uit deel 7 van de Verhandelingen, het algemeen nut na op een nauwkeurig bepaald terrein:

opheldering en uitbreiding der Natuurlijke historie, van talen, oudheden, zeden en gewoonten der Indische volken en andere bijzonderheden deze Landen betreffende bestemmen eigenaardig door plaatselijke betrekking het bijzonder doel van het Genootschap, welk tevens de bevordering van den Landbouw en andere aangelegenheden tot de welvaart der Volkplanting behoorende niet uit het oog zal verliezen (VBG 7, 1814:ix).

Toegevoegd aan de formulering uit 1800 was het element taalstudie. Ten opzicht van de oorspronkelijk doelstelling van 1778 was een inperking gemaakt. Het encyclopedische 'alle kunsten en wetenschappen' had toen voorop gestaan en de beperking tot 'deze volkplanting' had alleen gegolden op het terrein van landbouw, koophandel en bijzondere welvaart. De ongespecificeerde kunsten en wetenschappen waren nu ingeperkt.

\section{Publicaties}

Voor een nadere blik op de werkzaamheden van het genootschap in de jaren 1812-1815 zijn we aangewezen op twee toespraken van voorzitter Raffles van 24 april 1813 en van 11 september 1815 (VBG 7 en 8). Een apart programma, zoals in de periode 1778-1792 vijf maal was gedrukt, verscheen niet. Verder staan ons twee delen Verhandelingen ter beschikking.

In de eerste toespraak toonde Raffles zich een diplomaat door, als nieuwe voorzitter van een van oorsprong Nederlandse organisatie, aan de voorgeschiedenis ruime aandacht te besteden en tegelijkertijd een aantal belangrijke leden in het zonnetje te zetten: Radermacher, Ross, Muntinghe, Engelhard, Couperus en Van Naerssen. Twee van hen zaten ook in zijn eigen Council (VBG 7,1814:3-4,10, 16-7). Door de inhoud van deel 7 van de Verhandelingen samen te vatten stak hij opnieuw de loftrompet, nu op de buitenlanders, waarbij hij de werkterreinen noemde, die ook in de toekomst aandacht verdienden: natuurlijke historie (Horsfield), oudheidkunde (Mackenzie over Prambanan) en volkenkunde (Leyden over Borneo, VBG 7, 1814:11,14-6). Twee in deel 7 aanwezige Nederlandse bijdragen noemde Raffles niet: medi- 
sche wetenschap (Terne) en volkenkunde (Van Rijck), maar die waren dan ook al twintig jaar oud en werden in 1814 in feite herdrukt.

Als aandachtspunten en onderzoeksterreinen noemde hij vervolgens expliciet:

1 taalstudie, met name van het Javaans als toegangspoort tot de vroege geschiedenis van het eiland, alsook tot het denken en de gebruiken van de Javaan. Een plan voor een instituut voor taalstudie was in overweging. Het idee van gerichte studie van het Javaans was al onder Janssens geboren, mogelijk geinstigeerd door de jonge J. Chr. Baud, die onder Raffles in dienst van het gouvernement was gebleven. ${ }^{31}$

2 onderzoek naar gebieden buiten Java (voorbeeld: Horsfields onderzoek naar Bangka).

3 onderzoek naar inheemse wetten en instellingen (VBG 7, 1814:13-6).

Raffles concretiseerde tenslotte een aantal desiderata waarbij hij de Asiatic Society van Calcutta als voorbeeld stelde, die haar onderzoek over geheel Azië uitstrekte. Hij beval het Bataviaasch Genootschap aan zich vooral tot dichter bij Java gelegen gebieden te beperken. Hij noemde als onderzoeksgebieden: Bali, Borneo, Celebes, Halmaheira, Nieuw-Guinea, de noordelijke eilanden bij de Filippijnen en Japan (VBG 7, 1814:18-33). Daarmee gaf hij aan dat het Bataviaasch Genootschap beter de collega's in Calcutta niet in de wielen kon rijden.

Precies uitgewerkt is Raffles' programma niet, maar hij gaf wel aan welke gebieden aandacht moesten krijgen. Belangrijk zijn vooral twee aspecten: taalstudie en onderzoek naar nog weinig bekende gebieden. Hoe dat taalonderzoek, dan wel dat geografisch-etnologische onderzoek zou moeten worden aangepakt, daar gaat de toespraak niet op in. Dat Raffles zijn idee niet opgaf, blijkt uit het feit dat hij in 1823 in Singapore het Singapore Institute oprichtte voor de studie van de talen en culturen van Zuidoost-Azië (Van den Doel en De Schaepdrijver 1996:30-1).

In de toespraak van 11 september 1815, de vierde verjaardag van de Britse overname, deed Raffles evenmin een uitgewerkt programma uit de doeken, maar hij gaf wel een uitgebreid verslag van onderzoek dat door anderen was verricht, zonder steeds expliciet aan te geven of de resultaten van dat onderzoek door het genootschap zouden worden gepubliceerd. Na een lange lofzang op de overleden beschermheer Lord Minto, kwamen achtereenvolgens aan de orde: Horsfields verslag van zijn Bangka-onderzoek (dat in Londen zou worden uitgegeven), Borneo en Celebes (zonder vermelding van wie de soms zeer gedetailleerde onderzoeksgegevens afkomstig waren), Java (onder

31 Een instituut voor het Javaans kwam er pas in 1832 en wel te Surakarta (Fasseur 1993:60-3). Over Janssens' plannen om leerlingen voor het Javaans in Surakarta en Djokjakarta te plaatsen, aldaar p. 28. 
andere werden gemeld de opmetingen van tempels door captain G.P. Baker en het taalonderzoek door Reverend Th. Trowt), Bali, de geschiedenis van Java en tenslotte enige mededelingen over Japan (gebaseerd op mededelingen van Ainslie). ${ }^{32}$ Het overzicht geeft een interessante stand van zaken, waarin Raffles zowel de internationale literatuur over het onderwerp heeft verwerkt (W. von Humboldt, W. Jones, J. Banks, E. Kaempfer) als recente vondsten en beschrijvingen waarbij hij het ene tegen het andere afzet. Op verschillende plaatsen komt taalonderzoek ter sprake. Dat blijft een kerntaak voor het onderzoek in de archipel. Daarnaast blijkt uit de verslaggeving dat er in de voorliggende tijd gedetailleerd onderzoek was verricht en dat Raffles kon putten uit nauwkeurige verslagen. Als er geen in uitgewerkte doelstellingen en onderzoeksprojecten geformuleerd programma was, dan kunnen we toch uit deze redevoering aflezen waarover het in het Genootschap moest gaan. Raffles formuleerde zijn tweede verslag toen hij al wist dat zijn vertrek uit Java vaststond en tevens wist dat hij niet degene zou zijn die de overdracht aan de Nederlanders zou kunnen uitvoeren. Hij zou zijn ambt aan Fendall overdragen en naar Londen terugreizen. Toch is er in de toespraak van september 1815 niet direct van een afsluiting, laat staan van een afscheid sprake. Dat de toespraak pas na zijn vertrek verscheen, maakt het toch tot een afscheidsredevoering en tegelijk tot een programma voor de toekomst.

Raffles maakte op enkele plaatsen expliciet melding van onderzoeksresultaten die in de Verhandelingen zouden worden gepubliceerd: over Kawiinscripties gevonden in Oost-Java, Cheribonse manuscripten en ontcijferde inscripties op koperplaten, over de aard van het Javaanse schrift en over Tenggerse gebedsformules (VBG 8:36, 44, 53). In de Verhandelingen zijn echter deze beloofde opstellen niet verschenen. Moeten we aannemen dat deze opstellen behoorden tot het materiaal dat Raffles in 1816 meenam naar Londen voor deel 9 van de Verhandelingen, zoals aangekondigd in het voorberigt van deel $8 ?^{33}$ In 1816 keken de achterblijvers nog hoopvol uit naar dit in Londen te drukken 9e deel. In 1823, toen eindelijk deel 9 in Batavia uitkwam, waren er niets dan bittere woorden voor de niet nagekomen beloften van Raffles.

Wij verheugen ons dezelve [de 'keurige bouwstoffen' van het nieuwe deel 9] in de plaats te kunnen stellen der stoffe, waarvan in het Voorberigt van het VIII Deel dezer Verhandelingen melding wordt gemaakt, welke met de toenmalig afgetreden Voorzitter van dit Genootschap, den Heer Raffles, naar Engeland is medegegeven, ten einde aldaar de uitgave van het IX Deel te bespoedigen; doch wiens

32 VBG 8 (1816), Discourse, 5-11 (Bangka), 11-4 (Borneo), 14-23 (Celebes), 23-58 (Java), 58-69 (Bali), 70-86 (geschiedenis van Java) en 86-95 (Japan).

33 VBG 8:1,Voorberigt, dateert van na maart 1816. 'Drukte ter pers, en gedeeltelijk mangel aan de vereischte soort van drukpapier' worden hier aangevoerd als reden voor de late verschijningsdatum. We mogen aannemen dat verschijning in september 1815 in de bedoeling lag. 
beloften dien aangaande geheel onvervuld zijn gebleven, zonder dat de medegenomene, en aan zijne bezorging toevertrouwde stukken zelfs aan de Directie terug zijn gezonden (VBG 9:iii-iv).

Ook hier wreekt zich weer het ontbreken van het genootschapsarchief over die jaren, want in de verslagen van bestuursvergaderingen heeft ongetwijfeld een en ander gestaan over dit plan om deel 9 in Londen te laten drukken. De meegenomen en niet terugbezorgde stukken vormen een interessant raadsel. Dat Raffles beladen naar Londen terugkeerde, is bekend: dertig ton in tweehonderd grote kisten ${ }^{34}$ verpakt, teveel om op te sommen, maar in ieder geval ook veel geschreven materiaal dat hij voor zijn History of Java zou gebruiken. Met argwaan kijken we naar de bijlagen van dit werk (achter deel 2) waarin enkele interessante teksten voorkomen: uitgebreide woordenlijsten in bijlage $\mathrm{E}$ en $\mathrm{F}$, de verhandelingen over Celebes en Bali ( $\mathrm{F}$ en $\mathrm{K}$ ), en vertalingen van Kawi-inscripties (bijlage I). Raffles had in zijn toespraak van september 1815 over deze 'extensive vocabularies' gesproken, alsook over de te verschijnen Kawi-inscripties, terwijl er in dezelfde toespraak paragrafen gewijd zijn aan Bali en Celebes. Een deel van het 'Londense deel 9' lijkt aldus in Raffles' belangrijke werk over Java te zijn terechtgekomen. Toch hebben de bestuursleden van 1823, die Raffles' History kenden en die kennelijk zo bitter aan hem terugdachten, niet verder gewezen dan naar de man en niet naar de bijlagen in het werk, waar ze de bewijzen voor Raffles' handelwijze konden vinden. Dat Raffles dus kopij voor de Verhandelingen heeft gebruikt in zijn werk over Java, is door de bestuursleden in 1823 niet vermeld.

De bekende historicus van de Britse periode van Java en Raffles-deskundige John Bastin is niets bekend over een deel 9 van de Verhandelingen / Transactions, dat in Londen gedrukt had moeten worden. Hij verwijst echter wel naar de Malayan Miscellanies (1820-1821), twee door de Sumatran Mission Press in Benkoelen uitgegeven bundels Indonesianica, verschenen kort nadat Raffles het gezag in Benkoelen had overgenomen. ${ }^{35}$ Bastin suggereert dat eventueel vier van de verhandelingen in deel 1 en nog een vijfde in deel 2, stukken die niet direct op Sumatraanse zaken betrekking hebben, zouden kunnen behoren tot het Bataviase materiaal, in 1816 meegenomen naar Londen en in 1817 naar Benkoelen. ${ }^{36}$ Zo zou dan het 'Londense deel 9' ten dele in het grote

\footnotetext{
34 Niet meegeteld twaalf grote kisten met Horsfields verzameling. Die misten de boot en werden Raffles met de eerstvolgende mogelijkheid nagestuurd. Een collectie voor Sir Joseph Banks haalde Raffles' schip wel. Zie Bastins Memoir in Horsfield 1990:59.

35 Brief van John Bastin, 17-9-1996.

36 Het gaat om nr 2 over Bali, nr 7 over Timor, Roti, Savu, Solor, etc., nr 8 van J. Hunt over Kalimantan, nr 10 van J. Hunt over Sulo. Uit deel 2 noemt J. Bastin nr 9 van J. Methven over de Dayaks.
} 
werk over Java en ten dele in de Benkoelense delen kunnen zijn gedrukt. Omdat bij Raffles' vertrek uit Benkoelen in 1824 met het schip de 'Fame' ook zijn hele collectie en alle papieren in vlammen opgingen, is verder zoeken hiernaar weinig zinvol. De ondergang van de Fame met de levende have alle dieren kwamen om, maar alle passagiers, onder wie het echtpaar Raffles, konden worden gered - met een grote verzameling levende en gedroogde planten, met duizenden natuurkundige tekeningen en talloze manuscripten, oudheidkundige voorwerpen, muziekinstrumenten, enzovoort, enzovoort, is een culturele ramp geweest. Het tekent Raffles dat hij, terug in Benkoelen, in afwachting van een volgend schip direct aan de slag ging om een deel van de Sumatraanse gegevens opnieuw te verzamelen. Als Raffles in 1816 niet eerst naar Londen was gegaan met zijn tweehonderd kisten, had die ramp nog groter kunnen zijn geweest.

\section{Gebouwen: een nieuwe behuizing}

In de periode van Raffles' voorzitterschap valt nog een belangrijke gebeurtenis: de ingebruikneming op 24 augustus 1814 van de nieuwe genootschapslokalen op Weltevreden, op het terrein van de Sociëteit De Harmonie. De datum was veelbetekenend: de verjaardag van Prins Willem van Oranje, de pas aangetreden Souvereine vorst van Nederland, later Koning Willem I. Terwijl de feitelijke overdracht van de kolonie nog bijna twee jaar op zich zou doen wachten, werd juist op die dag het nieuwe lokaal betrokken tijdens een algemene vergadering onder Raffles, in het verslag waarvan expliciet naar de keuze van de datum wordt verwezen.

Op deze heugelijke dag, zijnde de Verjaardag van Zijne Koninklijke Hoogheid den Heere Prinse van Oranje, Souverein Vorst der Vereenigde Nederlanden, bepaald zijnde ter plegtige inwijding van het Nieuwe Locaal op Rijswijk, door het Gouvernement aan het Genootschap goedgunstig afgestaan. ${ }^{37}$

In de gekozen datum kondigden de nieuwe tijden zich al aan. De ingebruikneming vond aldus plaats twee jaar na de eerste belofte hierover van Raffles tijdens een ontmoeting met de leden, op 28 september 1812. Toen had hij - in de woorden van de krant - gesproken van 'a more commodious place for their meetings' (Java Government Gazette 31-10-1812:2).

De plannen voor de verhuizing van de Sociëteit De Harmonie van het gebouw in de Buiten Nieuwpoortstraat in de oude stad dateerden al van

37 OIOC Raffles Collection, Eur Mss 237 (Mss Eur F 31) Extract Resolutien Algemeene Vergadering Bataviaasch Genootschap 24-8-1814. 


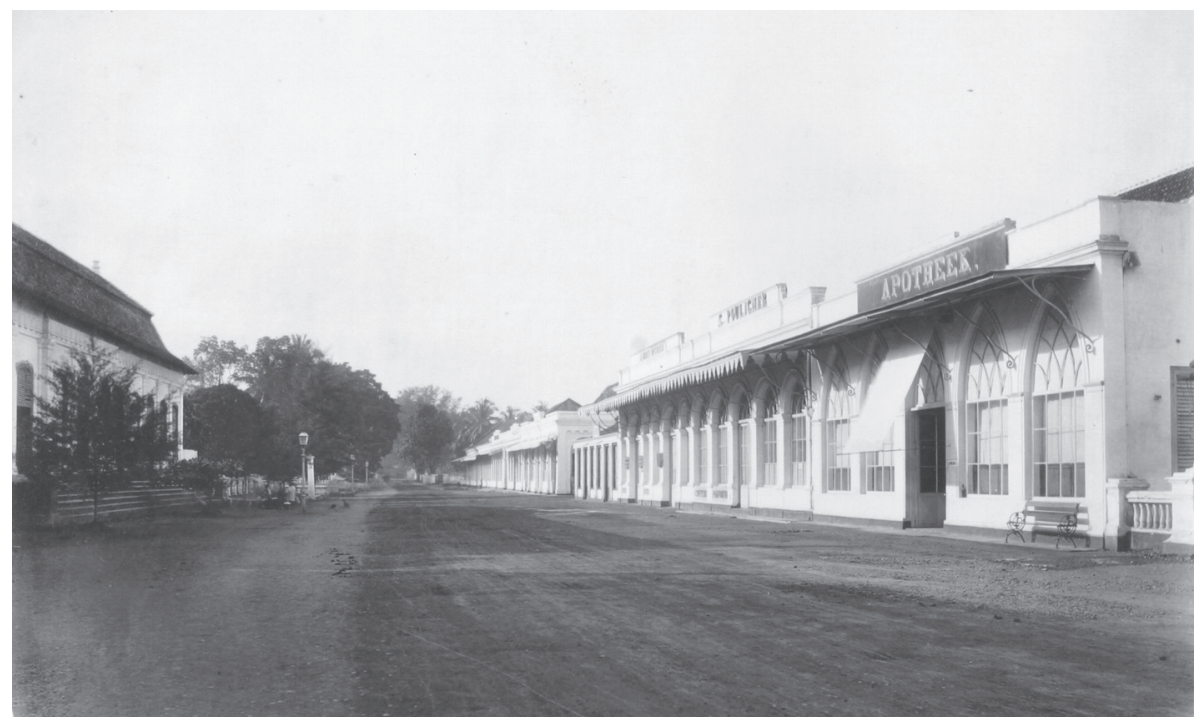

Rijswijkstraat met links gedeeltelijk zichtbaar het gebouw van het Bataviaasch Genootschap, gelegen achter het sociëteitsgebouw De Harmonie, Woodbury \& Page circa 1870 (collectie KITLV Leiden 26618)

1810. Daendels had echter toen alleen de sociëteit op het oog. Uit niets blijkt dat hij het Bataviaasch Genootschap in zijn plan had opgenomen. De werkzaamheden aan de nieuwe Harmonie waren gestart in 1810 en in 1811 gestaakt bij gebrek aan geld, maar ook omdat de dreigende aanval van de Engelsen verlammend werkte (Verhoeven 1939:19). Onder Raffles was de bouw grotendeels op basis van de plannen van 1810 hervat om pas in 1814 gereed te komen. Het Bataviaasch Genootschap betrok de nieuwe ruimte zelfs enkele maanden voor de Sociëteit zelf in het gebouw trok, het genootschap in augustus 1814, de sociëteit op 18 januari 1815. In feite moeten we niet van gebouw maar van een complex van gebouwen spreken. Het bestek laat een geheel zien van zeker acht gebouwen en gebouwtjes, voor een deel tegen elkaar aangelegen, onder meer het sociëteitshuis, twee aparte zalen, een kolfbaan, een woning voor de beheerder (kastelein), een achterbouw en een winkelcomplex. De voorgevel van de Sociëteit lag langs de Molenvlietse vaart op Rijswijk, de zijgevel aan de Rijswijkstraat, die naar het Zuiden, naar Tanah Abang liep. Het is niet onmogelijk dat Raffles in 1812, ten tijde van zijn belofte aan het genootschap, de Harmonie al in gedachten had. In juli 1812 was het nieuwe bestek voor het complex gemaakt en in oktober was de financiële kant van de zaak rond, juist in de tijd dat Raffles de leden van het genootschap bij zich thuis ontving. 
Het genootschap betrok in augustus 1814 de ruimte, oorspronkelijk bedoeld voor een galerij waar winkels en warongs in voorzien waren en die lag aan de Rijswijkstraat, aan de zuid-westzijde van het sociëteitsterrein. In het contract voor de aannemer werd het aangeduid als 'een gebouw [...] verdeelt in 10 vertrekken, ieder met twee vertrekken bestaande en bestemd tot 10 warongs, ieder vertrekje 10 à 12 voet' (Verhoeven 1939:525, 529-31). Het hele gebouw werd aan de buitenkant 110 voet lang en 26 voet breed (circa 33 bij 8 meter), een naar verhouding nogal ondiep gebouw. Aan de oorspronkelijke indeling zal wel het een en ander veranderd zijn want uit het genootschapsarchief blijkt niet dat men in 20 kleine kamertjes trok. Die winkels of warongs hadden de sociëteit door verpachting aan inkomsten moeten helpen, waardoor het de bouwkosten kon afbetalen, maar doordat het gouvernement de financiering overnam, was dit niet meer nodig.

Zo werd dan op de verjaardag van de souvereine vorst

des voormiddags ten $\mathrm{X}$ uuren de Heer Luitenant Gouverneur en President dezes Genootschaps Tho. S. Raffles door eene Commissie van twee Leden en de secretarissen van 's Gouvernements Huize afgehaald en alzoo binnengeleid zijnde, door alle de aanwezige Leden en een aantal Personen ter bijwoning dezer Plegtigheid toegelaten, eerbiedig verwelkomd. ${ }^{38}$

Hoe de plechtigheid verder verliep, werd niet gemeld. De krant had er alleen een vooraankondiging van gedaan op 20 augustus, waarbij gemeld werd dat het ieder lid vrij stond 'een paar vrienden, ter bijwooning dezer plegtigheid, door de byzonderheid van den Dag zo opgeluisterd, in te leiden' (Java Goverment Gazette 20-8-1814:2). De beschrijving van het ceremonieel doet erg denken aan de manier waarop de gouverneur-generaal in de jaren 1779 en 1790-1793 werd afgehaald door een commissie van in- en uitgeleide op weg naar de algemene vergadering.

Van de verhuizing van de verzamelingen van het genootschap ontbreekt elk spoor, terwijl het ons zou interesseren te weten wat er overgebracht werd van de oude naar de nieuwe stad. Of de museumcommissie in de periode van het Britse bestuur iets gedaan heeft, blijft een raadsel. Na de ingebruikneming werd het genootschapslokaal - zoals het steeds werd aangeduid - uitgeleend voor de bestuursvergaderingen van de Java Auxiliary Bible Society, waaruit we mogen afleiden dat het in ieder geval over een goede vergaderzaal beschikte.

In 1835 zou het genootschap ook de beschikking krijgen over het gebouw van de kolfbaan, gelegen naast het sociëteitshuis aan de Molenvlietsevaart,

38 Extract uit de resolutien van de algemene vergadering op 24-8-1814, in de Raffles Collection, OIOC Londen, Eur. Mss 237 (Mss Eur F 31). Dit uittreksel uit de resolutiën is het enige spoor van de resolutieboeken uit de Britse periode, dat ik heb kunnen vinden. 
aan de noord-oostzijde van het Harmonie-terrein. Toen de kolfbaan geen succes bleek, was daar de Algemene Secretarie in gevestigd geweest. F. Verhoeven wijst op de mooie combinatie in de jaren tot 1835: sociëteitsgebouw, genootschapslokaal en museum plus de kantoren van de Algemene Secretarie op een en hetzelfde terrein. 'Staatsbestuur, kunsten en wetenschappen, officieele feesten en sociëteitsgezelligheid broederlijk bijeen!' (Verhoeven 1939:531)

\section{Van Brits naar Nederlands}

Raffles' afscheid als voorzitter viel kort voor zijn vertrek naar Europa. Op 22 maart 1816 werd er een algemene vergadering gehouden, tijdens welke hij het voorzitterschap neerlegde en hem de eer te beurt viel een opvolger aan te wijzen, op suggestie van bestuurslid Van Sevenhoven. Raffles koos niet Muntinghe of Van Sevenhoven, maar de honoraire hoogleraar Ross, misschien vanwege zijn verdiensten als redder van het genootschap in de jaren tot 1811. Ook anciënniteit kan een rol hebben gespeeld. Ross was tenslotte de langstdienende. Het vice-voorzitterschap veranderde eveneens. Dit kwam bij Baron von Lutzow, terwijl Muntinghe naast Van Sevenhoven in de redactie van de Verhandelingen kwam te zitten. Moeten we aan een uitschakeling van Muntinghe denken of was hij bij het vertrek van zijn broodheer ook zijn belangstelling voor een bestuursfunctie kwijt?

Ross sprak bij de gelegenheid een dankrede aan het adres van de aftredende voorzitter uit, die de dag erna ook nog eens op papier aan Raffles werd overhandigd. De achterblijvers spraken de wens uit dat zij een borstbeeld mochten ontvangen van hun scheidende voorzitter 'om te worden geplaatst in de zaal van ons Genootschap in die leedige Nis, welke bestemd was om het Beeltenis te ontfangen van wijlen onzen edelen en geëerbiedigden beschermer de Graaf van Minto' ${ }^{39}$ Dat borstbeeld zou er ook komen, maar pas na ruim honderd jaar. Op 23 december 1929 werd het in de historische zaal van de vierde behuizing, het Museum aan het Koningsplein, door vertegenwoordigers van de Malayan Branch (Singapore) van de Royal Asiatic Society aan voorzitter $\mathrm{Ch}$. Welter overhandigd. Het siert nog altijd het Nationaal Museum in Jakarta. ${ }^{40}$

Raffles vertrok op maandag 25 maart 1816. Zijn neef Thomas Raffles

\footnotetext{
39 Java Government Gazette, 24-3-1816:1, zegt dat deze bijeenkomst op vrijdag 22 maart plaatshad. VBG 8:II (Voorberigt) zegt 16-3-1816. Het citaat naar de krant. De dankrede aan Raffles ook in de $V B G 8$ (1816).

40 Zie Verslag van de Openbare Vergadering der Directie van het Koninklijk Bataviaasch Genootschap van Kunsten en Wetenschappen, 23-12-1929, TBG 70:53-7 en het speciale Rafflesnummer van Inter-Ocean 9 (1930) aflevering 3.
} 
schreef later over de enorme vracht die hij meenam. 'This, then, was no small item in the expense of homecoming', schrijft Raffles' biograaf droog (Wurtzburg 1984:393). Bij al die vracht ook veel papier, onder meer de bouwstoffen voor zijn History of Java en de stukken die deel 9 van de Verhandelingen hadden moeten worden. Deel 8 was nog niet uit en zou na Raffles' vertrek verschijnen. Raffles' opvolger, John Fendall, gaf in de hem resterende vijf maanden geen blijk van belangstelling voor het Bataviaasch Genootschap. In de krant staat in die laatste maanden van het Britse bestuur niets meer over het Genootschap. Raffles stuurde in 1817 wel een exemplaar van zijn boek over Java aan het genootschap en Fendall wikkelde de zaak met Horsfield af: voor drieduizend Spaanse dollars ging het overgebleven deel van de collectie van de Amerikaanse natuurkundige naar Londen, ook dit deel dus niet naar het het museum van het Bataviaasch Genootschap (Horsfield 1990:60-6).

Raffles heeft veel betekend voor het Bataviaasch Genootschap: een opleving, een reorganisatie, nieuwe leden, hervatting van de uitgave van de Verhandelingen (na 20 jaar stilzwijgen), toegang tot de drukpers, een nieuw gebouw, inspirerende, programmatische bijdragen tot de vergaderingen en aan de publicaties, contacten met Britse onderzoekers. Het is niet gering en hij krijgt er terecht lof voor.

Raffles deed nog veel meer, dat niet het Bataviaasch Genootschap ten goede kwam: hij nam Horsfield over uit Nederlandse dienst, gaf hem faciliteiten, gebruikte Horsfields mogelijkheden en zag - toen de Britse regeerperiode afliep - kans om de Amerikaan voor de Engelse compagnie te behouden. Hij stuurde al in 1812 een deel van de Horsfield-verzameling naar Engeland - grotendeels in Nederlands dienstverband verzameld - en liet er in 1814 de steenvondsten van Bangka op volgen. Hij bracht Horsfield ook in contact met Sir Joseph Banks, president van de Royal Society, een groot verzamelaar, voor wie de Amerikaan tot vier keer toe een collectie gedroogde planten bijeenbracht. Raffles nam tenslotte een groot deel van de collectie persoonlijk mee naar Londen in 1816. ${ }^{41}$ In 1818 liet Raffles zijn adjudant, Captain Travers, op een diplomatieke missie naar Batavia vanuit Benkoelen, de Amerikaan ophalen, waarna deze vanuit Sumatra naar Londen vertrok (S. Raffles 1991:62830). Hoezeer ook de Nederlands-Indische regering van 1802 de kwaliteiten van de man had herkend, het is vooral via de Britse drukpers dat deze medicus-natuurkundige zijn kennis over Java wereldkundig heeft gemaakt in zijn vanaf 1821 in Londen verschenen publicaties. Vooral de Britse verzame-

41 Horsfield beschreef in 1829 in zijn 'Memorandum' voor Lady Sophia Raffles, die toen bezig was een biografie te schrijven over haar overleden echtgenoot, zijn (Horsfields) relatie met Raffles. In het memorandum wordt een deel van de correspondentie geciteerd waaruit blijkt dat de verhouding vriendschappelijk was (S. Raffles 1991:602-32). 
lingen hebben van zijn onderzoek op Java geprofiteerd. ${ }^{42}$ Daarentegen bleef er voor zover bekend slechts een kleine verzameling gedroogde planten van Horsfield in Batavia achter, de collectie die hij rond de jaarwisseling van 18051806 naar Batavia stuurde. Het betekende wel dat Reinwardt in 1816 en de Natuurkundige Commissie van 1820 niet konden voortbouwen op wat tussen 1802 en 1816 was verricht. Zij begonnen weer opnieuw.

De manier waarop Raffles een kundig cartograaf en historicus als Colin Mackenzie inschakelde bij het verzamelen van gegevens over Java, onder andere historisch-archeologisch materiaal, is een ander voorbeeld van zijn voortvarendheid. Het is tekenend dat Mackenzie's naam niet in het voorwoord van de History of Java voorkomt en dat Raffles hem zelfs in 1815 obstakels in de weg legde, toen deze via de militaire tekenaar H.C. Cornelius probeerde om zijn gegevens over Java aan te vullen. Raffles deed het verzoek van Mackenzie af als een particuliere zaak, die Cornelius niet hoefde te behandelen. Er hoefde geen aanvullend materiaal naar Calcutta gestuurd te worden. Zag Raffles Mackenzie toen als concurrent, die zelf wel eens met een studie over Java voor de dag zou kunnen komen (De Haan 1935b:603-4)? Anderszins is Raffles' teleurstelling en verdriet over het overlijden van Dr. John Leyden in de eerste weken van het Britse bestuur op Java een bewijs van zijn hoop dat Leyden zijn kennis had kunnen inzetten voor de studie van Javaanse zaken. En dat op een moment dat Raffles nog helemaal geen plannen had om zelf een boek over Java te publiceren. Leydens bijdrage aan de Verhandelingen bleven daardoor beperkt tot aantekeningen over Borneo, gemaakt op de heenreis naar Batavia.

Raffles zag het belang in van de studie van Javaanse tempelresten. Misschien wordt hij wat teveel als de 'ontdekker' van de Boroboedoer geprezen, waar immers mannen als Engelhard - jammer genoeg zonder respect voor de tempels - eerder Javaanse oudheden exploreerden en exploiteerden, maar het feit dat hij het onderzoek op gang bracht, als nieuwsgierige stimulator optrad en zelf ook de tempels ging bezoeken, zegt genoeg over de onderzoeksdrift die noodzakelijk is om de wetenschap vooruit te helpen. Dat het Bataviaasch Genootschap er op dat moment weinig tegenover kon zetten en daardoor bij het vertrek van Raffles een groot verlies leed, zegt genoeg over het zittende bestuur en over de leden.

Raffles' betrokkenheid bij de Bataviase maatschappij blijkt tenslotte ook nog uit het feit dat hij de Java Auxiliary Bible Society aanvoerde, het societeitsleven stimuleerde - gesteund door een vrouw die Europese elegantie in Batavia terugbracht - en de Java Benevolent Institution oprichtte, die de

42 Bastin in zijn Memoir, Horsfield 1990:43, 49, 55-7, 59-63 over de verschillende verzamelingen die niet voor het Bataviaasch Genootschap bestemd waren. 
afschaffing van de slavernij voorstond (Van de Wall 1930). Daaruit bleek dat zijn aandacht niet ophield bij wetenschap. In veel opzichten volgde Van der Capellen Raffles' voetsporen, zodat eerder 1811 dan 1816 als een breuk kan gelden, ook voor het genootschap. Doordat Raffles het genootschap nieuw leven inblies, hoefde Van der Capellen dit niet boven aan zijn lijst van werkzaamheden te stellen en kon hij zich eerst aan andere zaken wijden. 